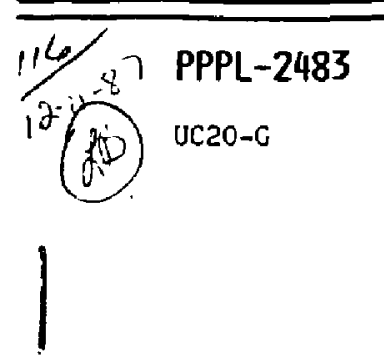

SELF-CONSISTENT, THREE-DIMENSIONAL EQUIL'BRIUM EFFECTS

ON TOKAMAK MAGNETIC FIELD RIP .E

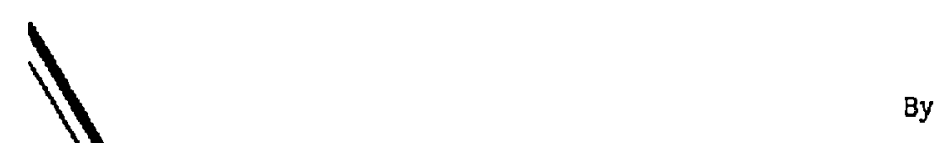

J.L. Johnson and A.H. Reiman
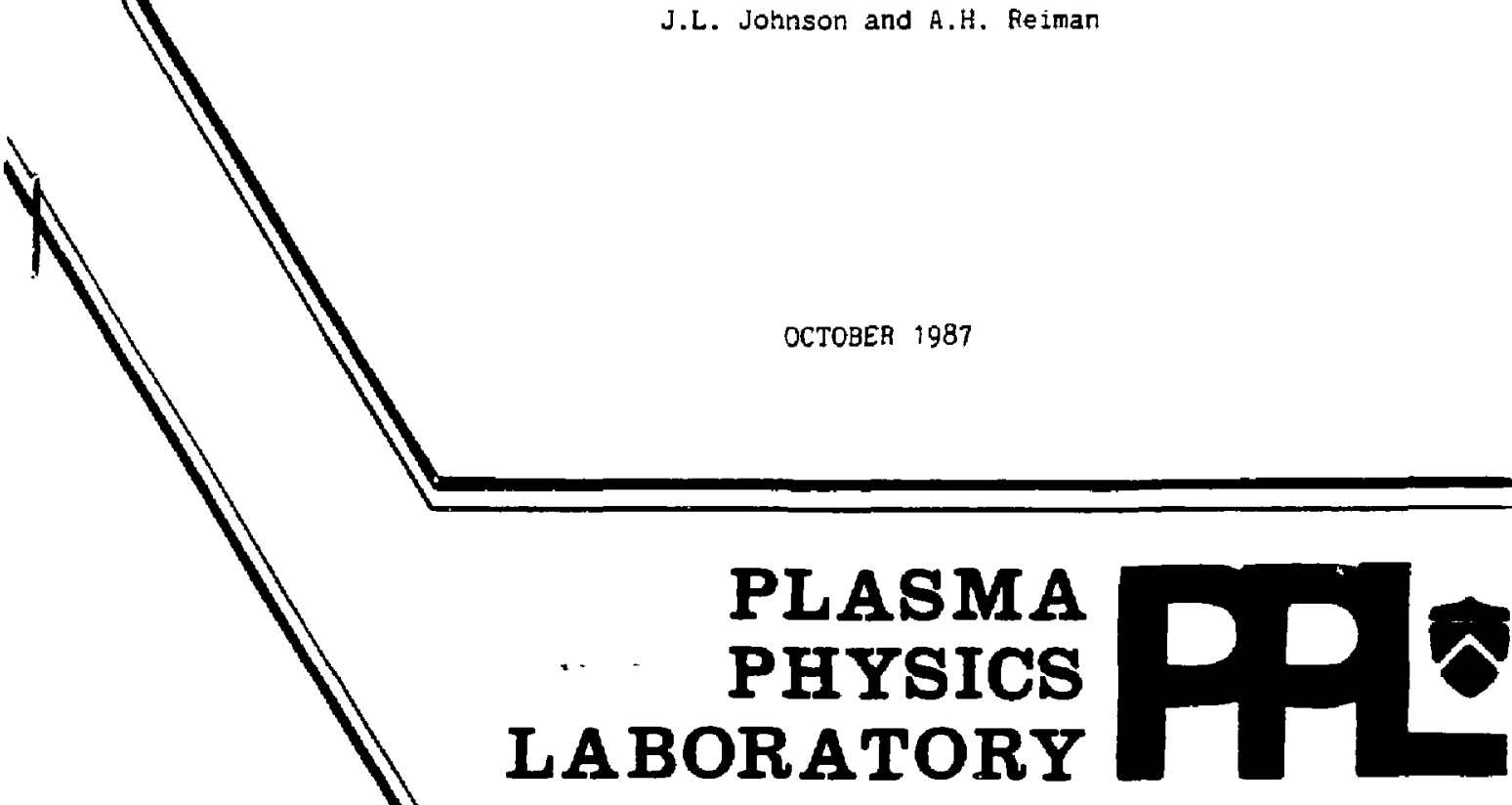

PRINCETON UNIVERSITY

PRINCETON, NEW JERSEY

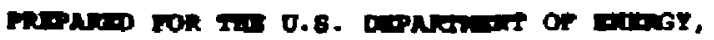

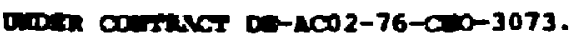




\title{
SELF-CONSISTENT, THREE-DIMENSIONAL EQUILIBRILM EFFECTS ON TOKAMAK MAGNETIC FIELD RIPPLE
}

\author{
J. L. Johnson and A. H. Reiman \\ Plasma Physics Laboratory \\ Princeton University \\ Princeton, NJ 08544
}

\begin{abstract}
Self-consistent equilibrium effects $c$ n tokamak magnetic field ripple have been calculated using a three-dimensional equilibrium code. The effects are found to be large enough that they should be included in tokamak ignition experiment designs. Even the modification of the well depth associated with the flow of force-free plasma current along rippled field lines is substantial. An analysis of the results separates the contribution of the Shafranov shift to the ripple modification from the contributions of other finite-pressure effects.
\end{abstract}

\section{DISCLAIMER}

\begin{abstract}
This report was prepared as an account of work sponsored by an agency of the United States Government. Neither the United States Government nor any agency thereof nor any of their employees. makes any warranty, express or implied, or assumes any legal liability or responsibility for the accusacy, completeness, or usefutness of any information. apparalus, product. or ence herein to any specific commercits use would not infringe privately owned rights. Relermanufacturer, or otherwise does nol product, process, or service by trade name, trademark. mendation, or favoring by the United States Govertitute or imply its endorsentent, recomand opinions of authors expresed tates Governmenl or any agency thereof. The views United States Government or any agency thereof.
\end{abstract}




\section{IN!)}

The axisymmetric two-dimensional character of lakamak configurations has made them popular camdidates for fusion devices. The comst ram astosiated with this symetry shudd make them particularly effective for plasma comfinement. The sit uat ion in an act ual

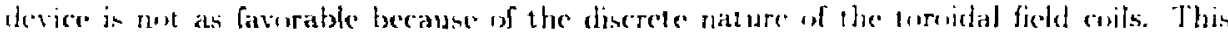

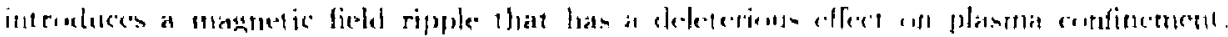

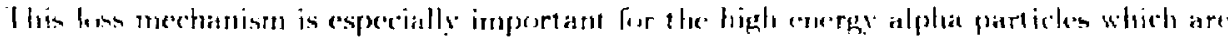

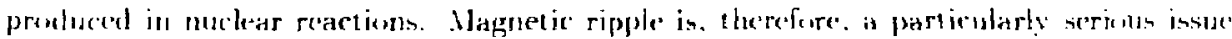
for ignilian experiments.

birce the cost of a lusion devide depends critically on buth the mumber and sige of the turovial field coils. the determination of the magnitude af the maguetic fiedal ripple is an important and integral part of machine design. The werk that has loen wome up until mom has been based on analy'sis of vacuum ripple fields. However. morrents iu the plasma can modify the ripple amplitude. Because of the existence of a threshodd effect. a small increase in the ripple cuagritude can leat to a dramatic increase in alpha particke loss 1 . It is therefore important 1, moderstand the chafges in the nature and magnitude of the ripple field fron the predictions of the simple vacuum field approximation.

Plasma rurrents can mulify the ripple esen at $f$ b\%, due 1 , the How of the Ohmic current atong rippleal ficld linc's. At finite 3. the most obvious effect is the Shafranow shift. an outward displarement of the magnetic surfaces due to the magnetic indurtion and the Pfirsch-Schlizter current. This could provide significant enhancement of the ripple magnitude by moxing the flux surfaces to regions where the ripple is large. The size of this effect can be est imated by using axisymetric magnetchedrudynamic (AJHD) calculations ie determine the mignitude of these shifts as the pressure in increased. A more subtle effect of plasma pressure is the mesdification of the ripple fiedd magsitude :ise to the flu w of Pfirsch-Schlïter currents along rippled field lines. There is alsu an effert due to the P'firsch-Schliuter currents which are generated by the ripple (i.e. hy the change in curralure

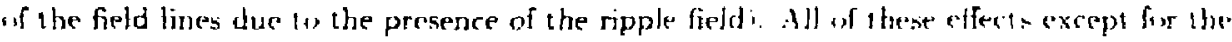
Shafranov shift require a fully three-dimensional corle for their calculation.

We deseribe cur tacils. model. and calculations in the next section and aliscuss our results in sectirn 11 l.

\section{MOBDEL}

Our principal tool for invest igating the effert of plasma pressure on the magnitude of

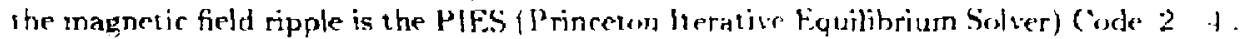
It uses an iterative procedure whore the magnetic ficld and pressure are assumed to be known at any given step and an improved current distribution is calculated. The new magnetic field. and thus the pressure, is calculated from this current. and the iteration process is continued until a selfoconsistent equilibrium in achieved.

In order to vary as fen plasma paraneters as pessible in naking a comparisen. we treat equilibria with a fixed plasma surface: in this work our base configurations have

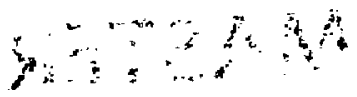




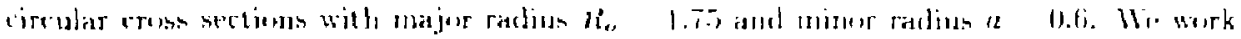
vill an pressure distribution

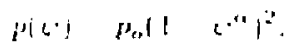

and is sitfely factor

$$
q(1 \cdot) \quad q_{r} \cdot\left(q, q_{n}\right) u^{2} .
$$

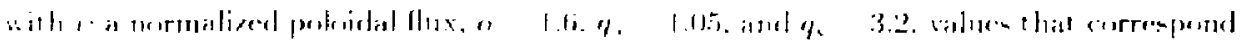

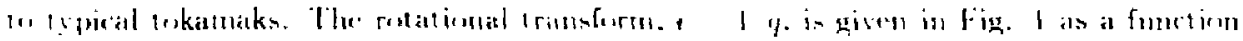
of $p$ a surface label which measures the maximben radius $h_{z}$. of the surface and raries

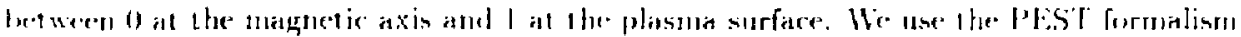

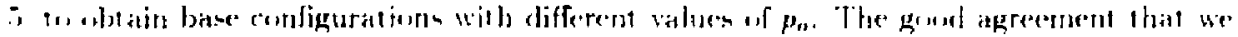

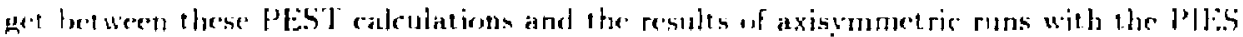

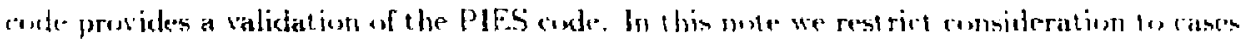

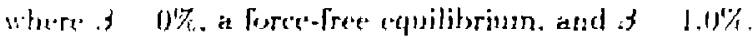

We model the biscreteness of the torojdal ficld coids by treating them as if they were wry thin. had very large elliphicits athd were shaped so as to spread the current sinusudally ist the terojdal angle o. There we have a current $l$ at the axis $K$ ll, and

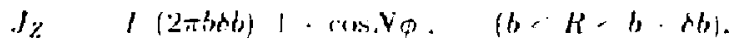

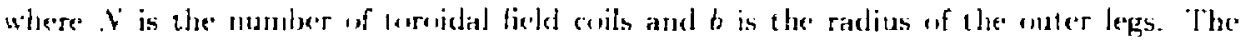

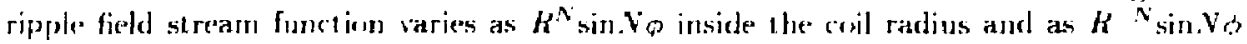
sidsicle. so that the external!y imposed magnetic field ran be taken as

$$
\text { В } 2 / \Gamma\left\{\phi \cdot(R / b)^{3} \cdot 2 . V \sin F \phi\right\} . \quad(R<b)
$$

Wi typically fix the coil mumber $y \quad 16$ and radius $b$. 3, which gives us a field ripple of alusit $1 \%$ at the plasma surface.

Me foud it cromenient le introduce this field ripple onte the equilibria that we obtain from the PEST conte by rhanging the shape of the buundary surface. rather iban by inereduring the fiekd jtsedr. Thus we use Eq. (-1) and the equation along the field lines

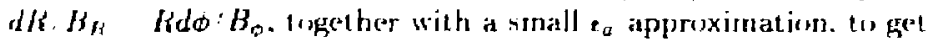

$$
\begin{aligned}
& h \quad R_{a}\left\{1 \cdot\left(R_{n}: b\right)^{N}: 2 . \cos N o\right\} \text {. } \\
& \text { \% } Z_{n} \text {. }
\end{aligned}
$$

with $K_{n}$ and $Z_{a}$ defining the pesilion of the axistmmetric busndary, and with $t_{n}$ the iransform at the boundary.

A variation of this model that we hase also insestigated was constructed by fixing

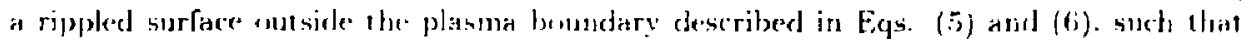
several compustional surfaces exist in the waum region between the plasma surface and the wall. We then obtain a unt af erpulithrias with sirnilar pressure profilas and with the

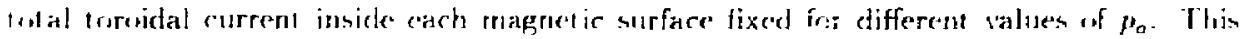


prevides a different measure of 1 he effeces of changing 3 in a free busudary system where the plasma temundary is displaced ant ward by the Pfirsch-bohliiter currents.

lie first discuss the fixed boundary calculations with $p(*)$ and $q\left(c^{\prime}\right)$ prescribed. The' magnet ic surfaces at 8011 are given in Fig. $2 a$ for the furce free configuration and in Fig.

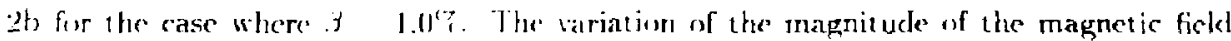

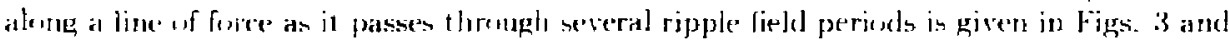

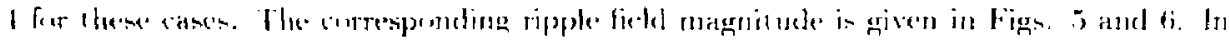
all if these figures, we follow lines on magnetic surfaces that pass thesugh their outerment

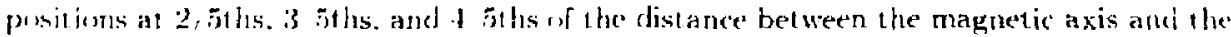
plasma bumdary and at the busmdary itself. In alternate way of vieneing the re'sults is te compare the variations of the field magnitudes with of for the total lield. the ripple field.

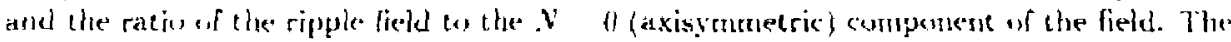
results given in Figs. T through 9 are for surface 16 . 1 'thts of the way out. The quantities in Fig. 9 have been mormalized to their value at the plasma busndary.

Our results are summarized in Table 1. The surfaces for which the data is given are the sane as those used for the figures. The first column gives the values of the function $\left(B_{\mathrm{L}}, B_{s}\right):\left(\boldsymbol{R}_{\mathrm{v}} \cdot R_{s}\right)^{N}$, with $B_{u}$ the maximum ripple fiek on a magnetic surface. $B_{s}$ that at the plastna surface, and $R_{v}$, and $R_{s}$ the corresponding radial pesitions. If the inly change in the ripple magnitude were due to the displacement of the surface, these numbers would all be unity. Ancther measure of the ripple field magnitude. the function $\left\{B_{s}, B_{s}\right\}_{j=1 \%}\left(B_{v}, B_{3}\right)_{3=0 \%}$ is given in the second column.

kesults using the free boundary model, normalized to the field at the plasma boundary: are not much different from those where the plasma surface is kept fixed. For B-values up $1 \mathrm{a}$ I $\mathrm{C}$ the rotationai transform inside the plasma is not changed much at fixed current from what it was for the force free case. The scaled ripple field on surface 16 for this case is given in Fig. 10. The functions $\left(B_{v} / B_{s}\right) !\left(K_{w} / R_{s}\right)^{N /}$ and $\left(B_{v} / B_{s}\right)_{s=1 \% !}\left(B_{v} / B_{s} / s-n \%\right.$ for this case are also giten in Table 1.

\section{DISCI'SSION}

Self-cronsistent equilibrium effects increase the severity of the ripple problem. We have not seen any case "here the equilibrium effects shield the ripple and recrease its magnitude. The effert is always $t$ dectease the rate a: which the ripple strength decays is going towards the plasma center. Even at 3 .- $0 \%$. the effect of the ripple field extends surprisingly far inward. As can be seen in Figs. 3 and 5. the ripple is noticeable even $3.51 \mathrm{th}$ of the way out. even though only about a $17 \%$ ripple is imposed at the plasma surface. The introduction of plasma pressure increases this effect.

In the first column of Table I. we have nomalized the fields to compensate for the if dependence of the vacuum magnetic field. (i.e. If the ripple field were strictly the externally imposed vacuum field. all thesp numbers would be unity.) At the same time, we have compensated fir the Shafranor shift by using values of $R_{v}$ cosresponding to the shifted

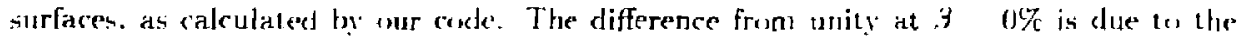
flow of the ohmic clerent along rippled field lines. Increased current densities associated with shaped cross sections would be expecied to increase this effect. For example. for the 
Shaping being contemplated for the Compart Ignition Tokamak (CIT) the colindrical q would be decreased by a factor of about two. so that we could expect this effect ta be increased by a similar factor.

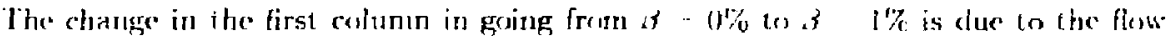
of the Pfirsch-Schlüter currents along rippled ficld lines. as well as to the Pfirsch-Sehlïter currents gentertlod by the ripple. For this rather medest $1 \%$ walue al 3 , the effert is

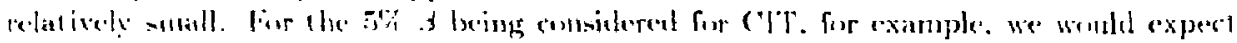
cffects at least five times as large. Such effects conld be important.

The ripple field given in the second column in Table 1 has been nurmalized to the $.3 \quad 0 \%$ field. Tlius, these numbers do not include the zero 3 ripple effects included in column 1. They do include the eflects of the Shafranus shift. Again, the effects would be larger for the values of $\$$ being comtemplated for ignition experiments. 'The affect of s]aping would be to decrease the Shafranon shift. atul. therefore. lessen the severity of this cont ribution to the ripple.

The ain of this note has been to give a foel for the magnitude of the effects being neglected in present ripple models. On the basis of the se results we fecl that more ext ensive sludies are warranted. In particular. we believe that these effect.s shuuld be taken inte accuunt in the design of ignition experiments.

\section{ACKNOWLEDGMENTS}

This problem was first suggested to us by Dr. A. H. Bouzer. We are also grateful to him and to Dr. H. S. Greenside for several useful discussions. We are indebted to Dr. J. Manickam for providing us equilibria from the PEST code. This work supported by the [ $\because$. S. Department of Fnerg: under Contract No. DE-AC02-76-CHO-3073.

\section{RFFERENCES}

1 Goldston, R.J.. White, K.B., and Boozer, A.H.. Phỵs. Rer. Lett. (1981) 47, 647.

2 Reiman. A., and Creenside. H., Comput. Phys. Commun. (1986) 43, 157.

3 Reiman. A. and Greenside. It., Numerical Solution of Three-Dimensional Magnetic Diferential Equations, to be published in J. Comp. Phys.

4 H. S. Greenside, A. H. Reiman, and A. Salas. A Nonvariational Cude for Calculating Three-Dimensional MHD Equilibria, submitted to d. Comp. Phys.

5. DeLucia, J., Jardin, S. C.. and Todd, A. M. M.. J. Comput. Phịs. (1980) 37,183. 
TABLE I. Kipple field arialions on different magnelic surfaces.

$\beta$

$$
\text { Surface }
$$

$$
\left(H_{w} ; H_{s}\right) ;\left(K_{w}, K_{s}\right)^{N}
$$$$
\left(B_{v} ; B_{s}\right)_{B} /\left(B_{v} ; B_{s}\right)_{\perp} \text { i } \%
$$

Constant $t$. fixed boundary̧. normalized $(1$, plasma surface

$0.1 \%$

$\begin{array}{ll}201 & 1.016 \\ 16 & 1.09 \\ 12 & 1.21 \\ 8 & 1.37\end{array}$

$1.0 \%$

$\begin{array}{lll}20 & 1.00 & 1.00 \\ 16 & 1.14 & 1.12 \\ 12 & 1.29 & 1.24 \\ 8 & 1.19 & 1.37\end{array}$

Constant $I$, free boundary, normalized to plasma surface

$1.0 \%$

20
16
12
8

1.00

1.00

1.11

1.29

1.11

1.50

1.28

1.46 


\section{FIGLRE CAY'TOSS}

Fig. 1. Rostational transform, $+1, q$ as a function of $\rho$. the maximum ma jor radius of a magnet is surfare scaled to be 0 at the magnetic axis and 1 at the plasma broundary:

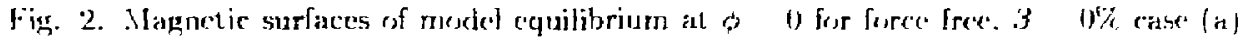
and for .5 l. $1 \%$ (b).

Fig. 3. Variation of the todal magnitude of the magnetic field along a fiedd line at surfaces

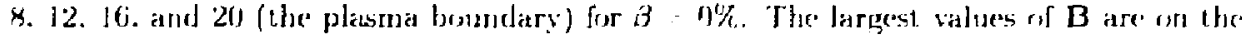
inner surfaces because of the $1 / K$ deperedence of the torsidal field.

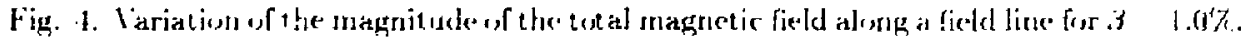

Fig. ¿. Variation of the magnitude of the ripple magnetic field along a fiedd line for it . G\%.

lig. 6. lariation of the magnitude of the ripple magnetic field along a field line for $.1 .6 \%$

Fig. 7. Variation of the magnitude of the magnetic field along a field line on surface 16 , f: 5 ths of the way between the magnetic axis and the plasmia boundars. The solid curve is for $3-0 \%$ and the dashed one is for $3=1.0 \%$.

Fig. 8. Variation of the magnitude of the ripple magnetic field aleng a fiedd line on surface 16. The solid rurve is for .3 - $0 \%$ and the dasherl rone is tor .3 $1.0 \%$.

Fig. 9. lariation of the ratio of the magnitude of the ripple magnetie tield to that of the axisymmetric (o) o) component of the total field along a field line un surface 16 for the ralculations with a fixed plasma brundary. The ratio has been normalized to its value at the plasma boundary. The solid curve is for $B=0 \%$ and the dashed one is for $B=1.0 \%$.

Fig. If. lariation of the ratio of the magnitude of the ripple magnet ic ficld to that of the axisymmetric $(: V$ (j) component of : the total field along a field line on surface 16 for the calculations with a free plasma boundary. The ratio is again normalized to its value at the plasma boundary. The solid curve is for $\delta^{\prime}-0 \%$ and the dashed onc is for $3-1.0 \%$. 


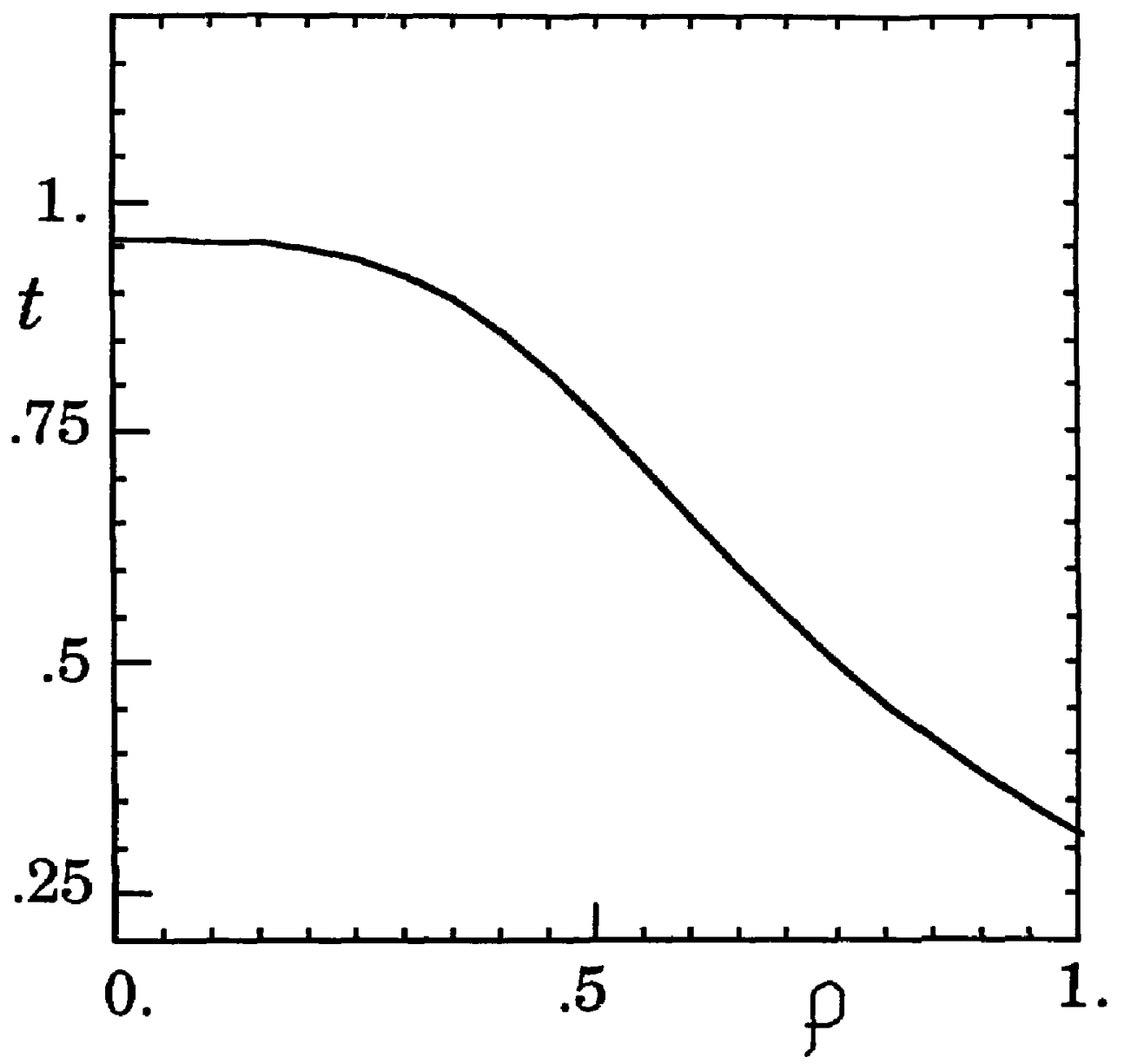

Fig. 1 


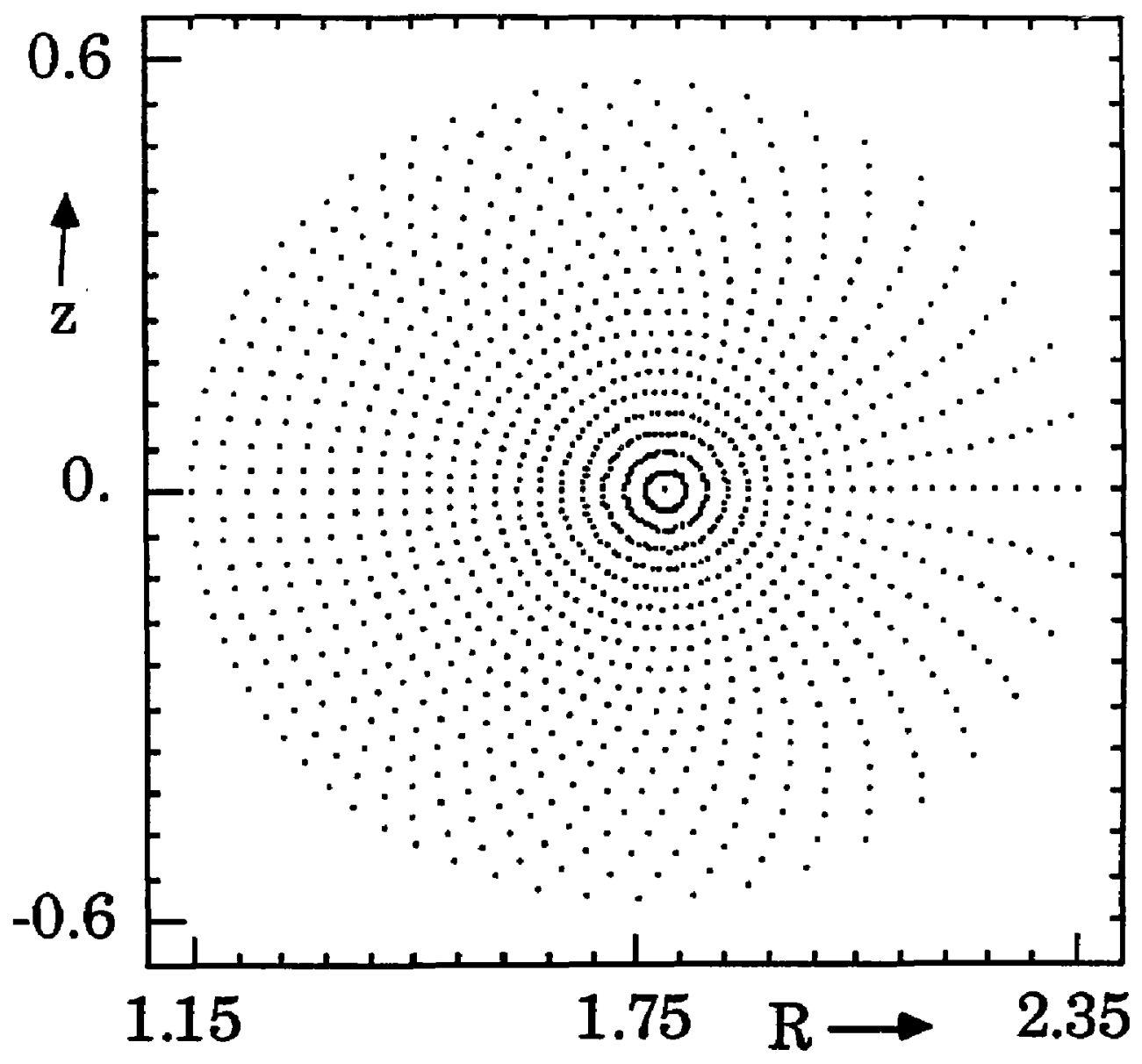

Fig. 2 (a) 


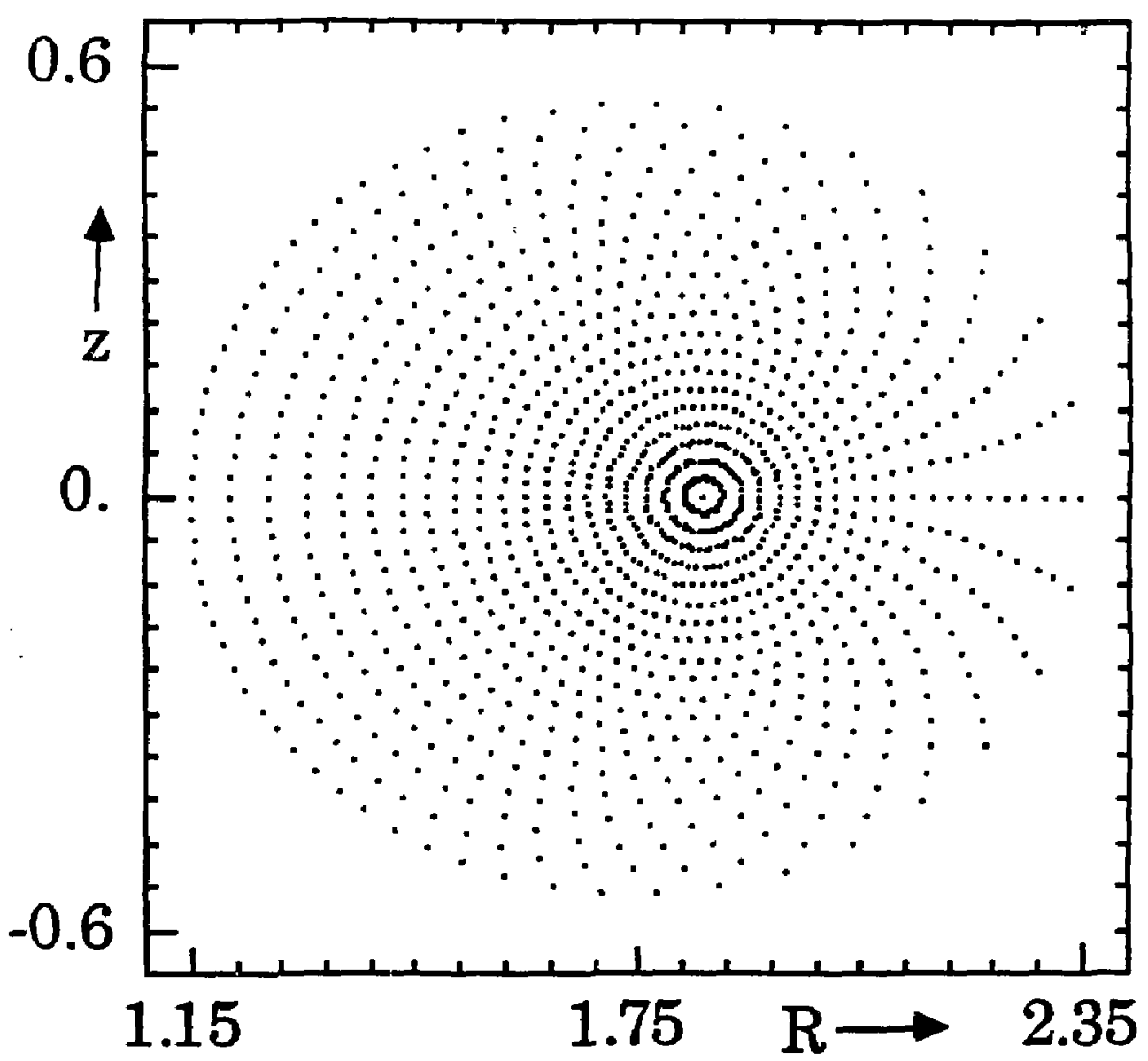

Fig. 2 (b) 


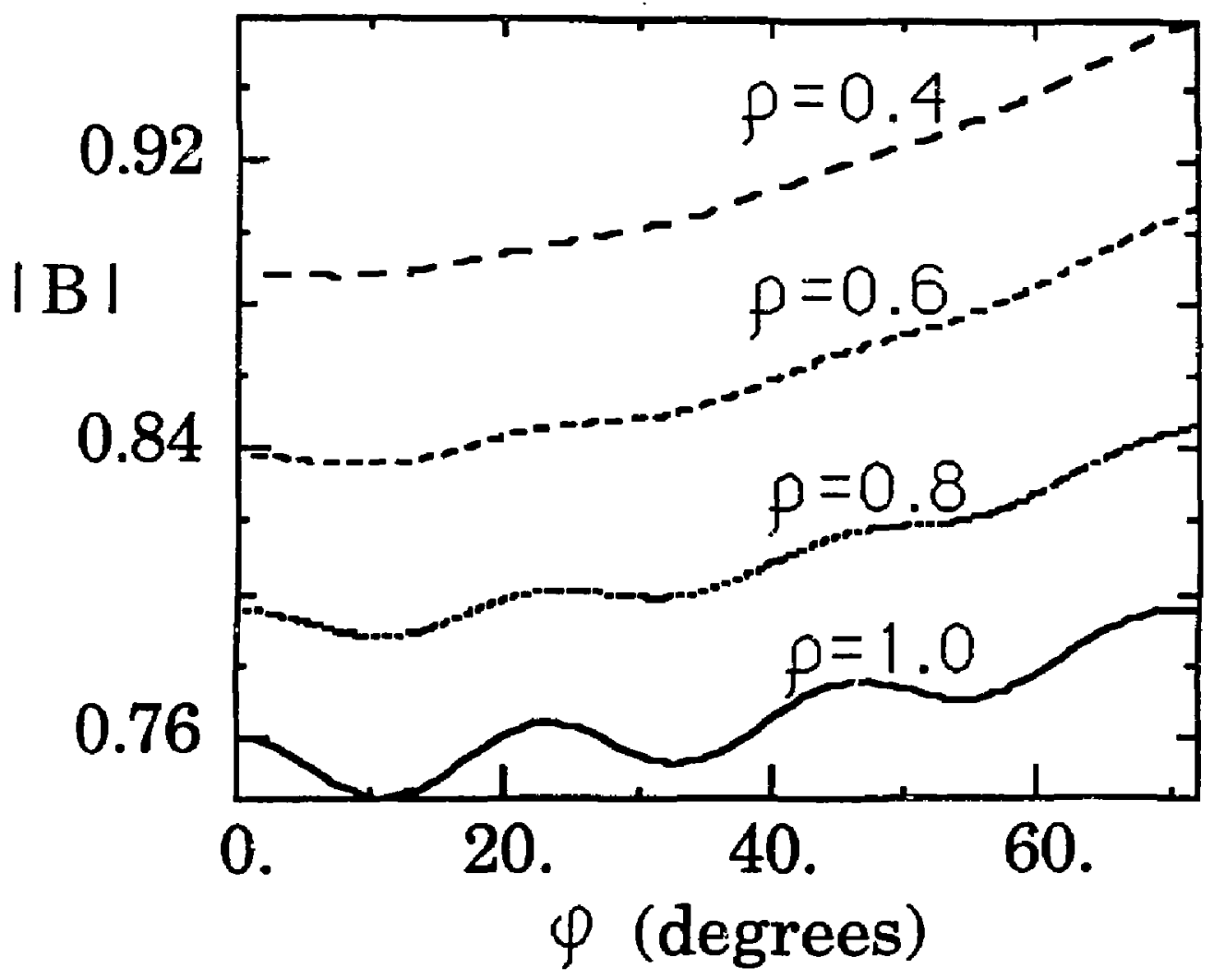

Fig. 3 


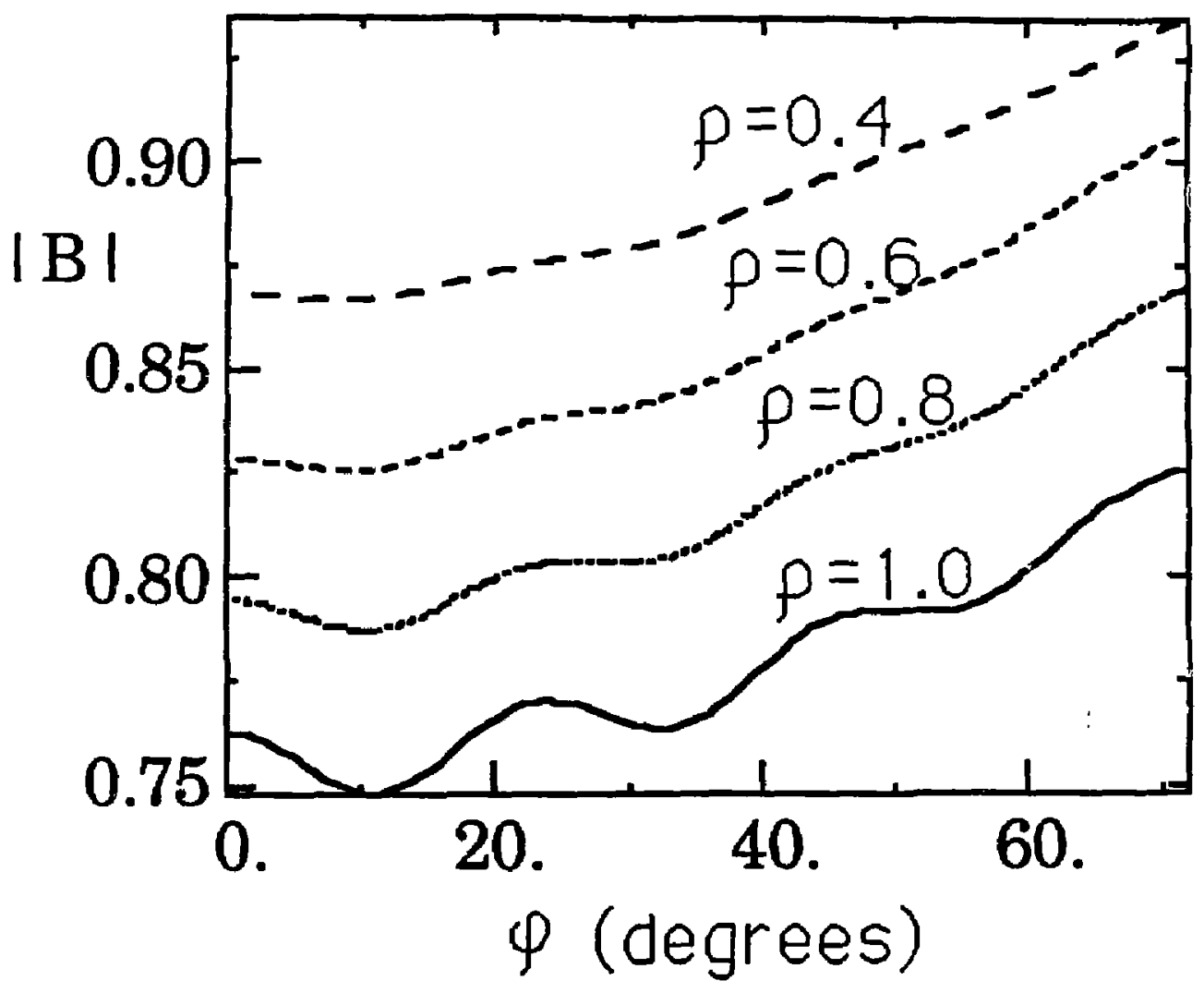

Fig. 4 


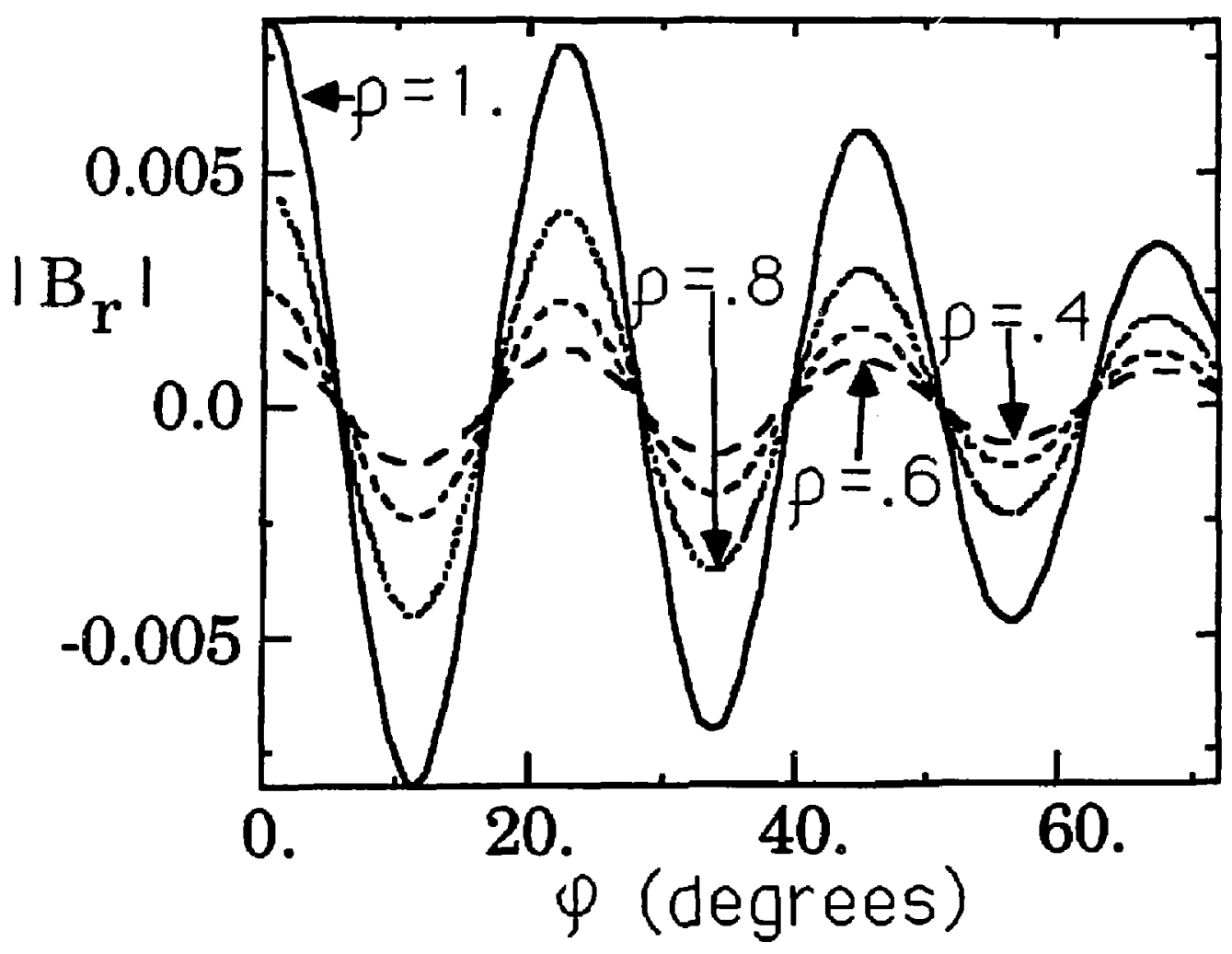

Fig. 5 


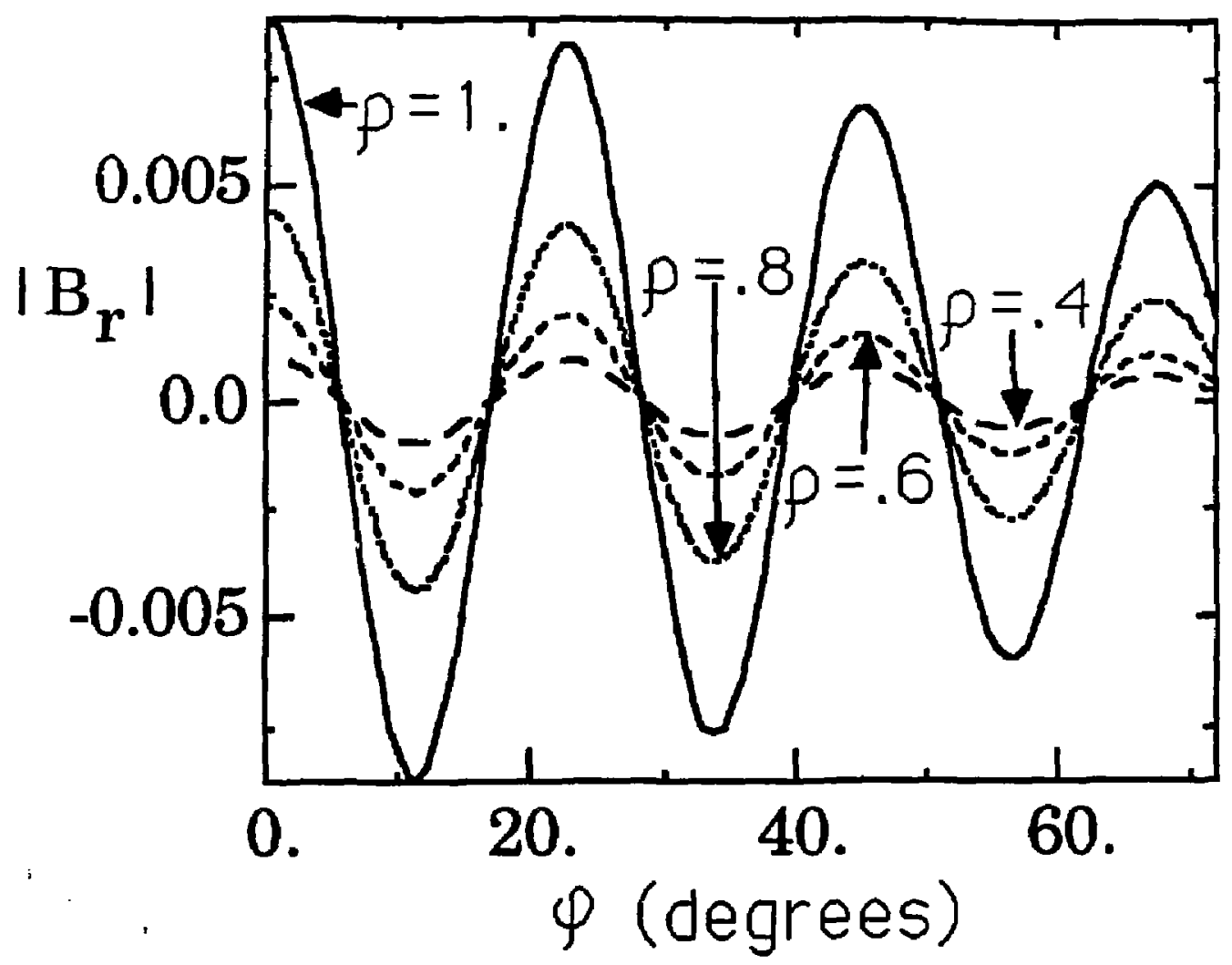

Fig. 6 


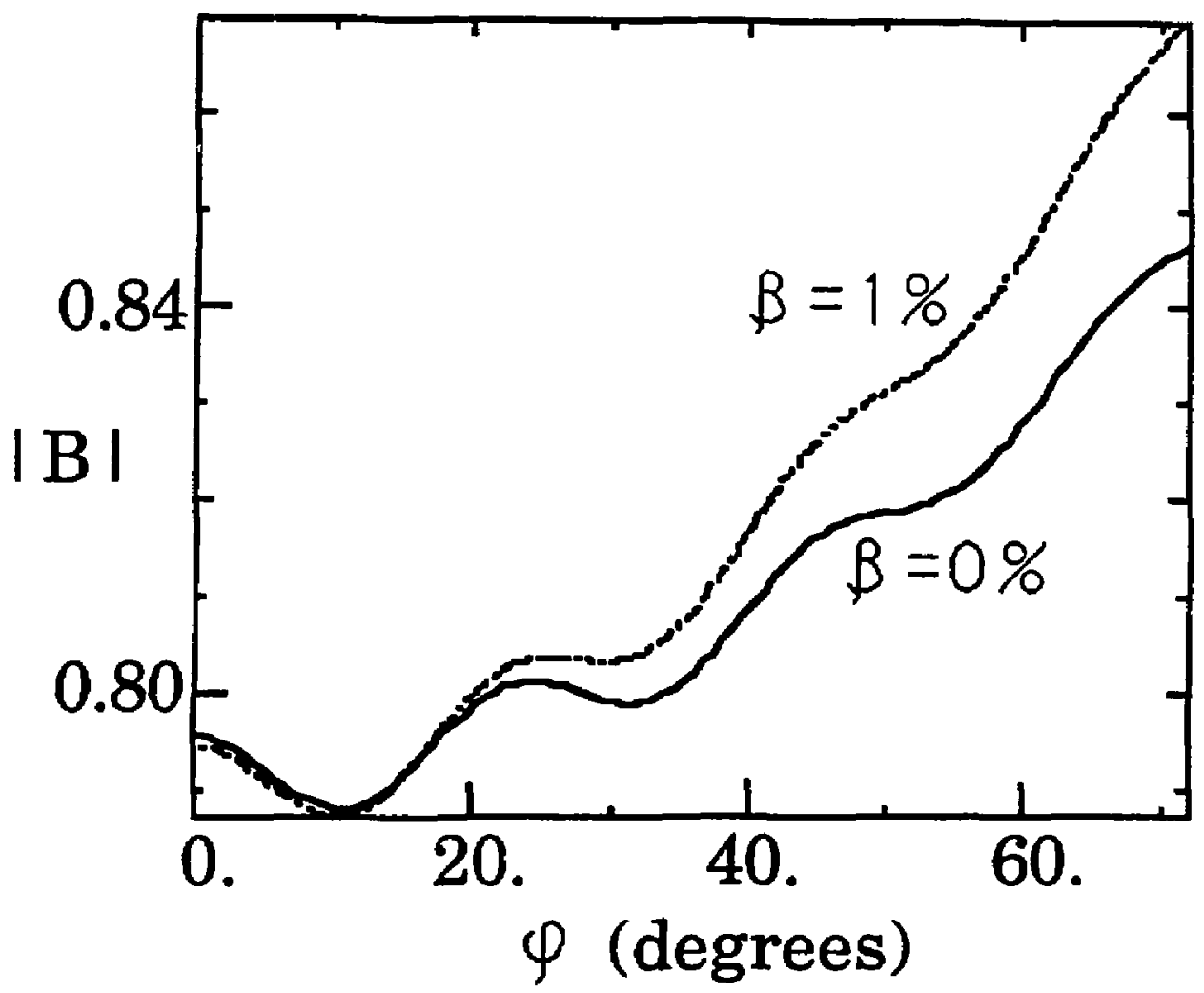

Fig. 7 


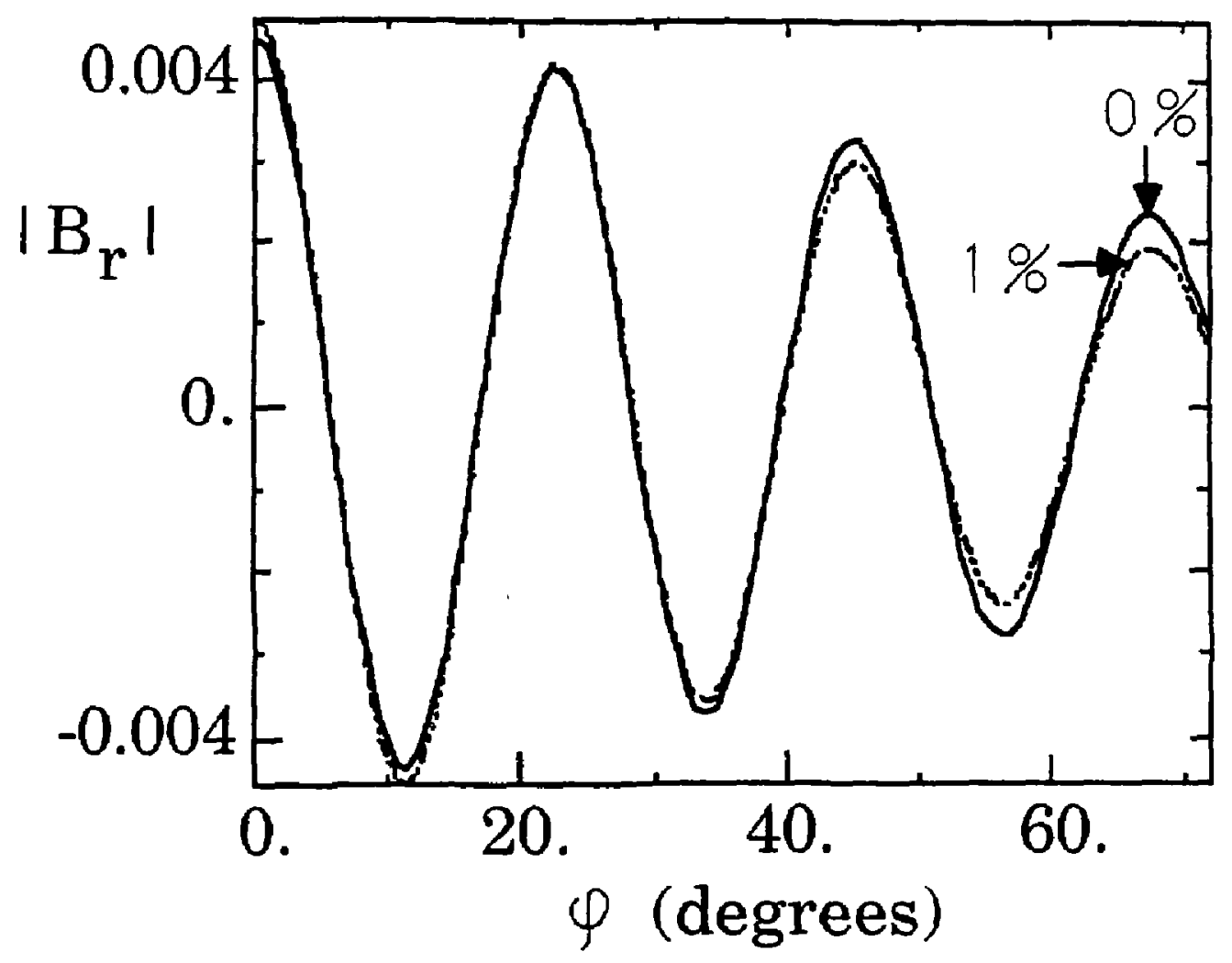

Fig. 8 


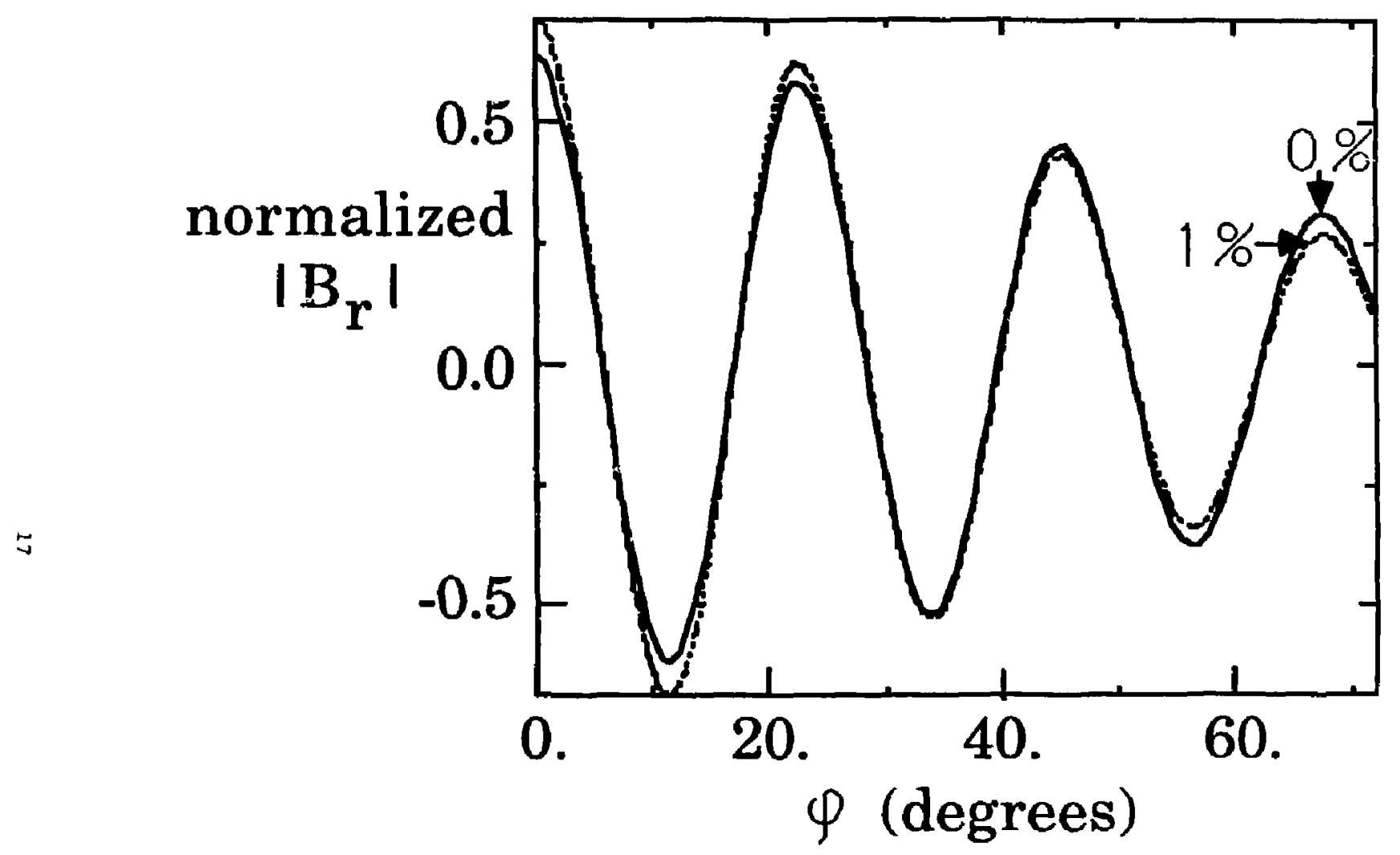

Fig. 9 


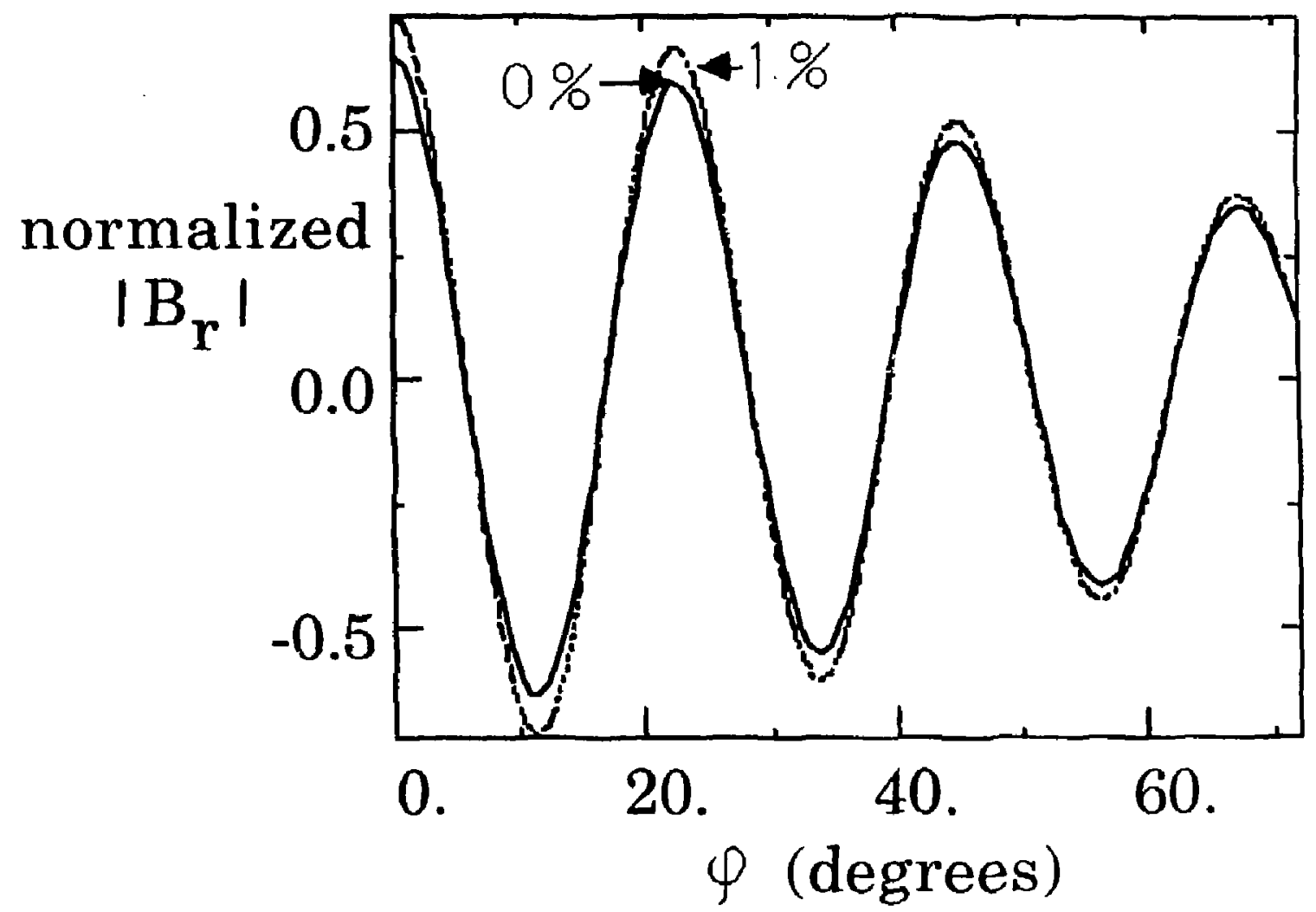

Fig. 10 
Dr. Frank J. Paoloni, UnIv of wollongong, MUSTRALIA Prof. H.H. Brannan, In IV Sydney, AJSTRALIA Plasma Resgareh Lab., Austral lan Nat. JnIv.., AUSTRalia Prof. I.R. Jones, FIInders Univ... AUSTRA IA Prof. F, Cap, inst Theo Phys, AUSTRIA Prot. M. Holndler, Institut tur Theoretische Physik, AUSTRIA M. Goossens, Astronomisch instituut, BELGIUM Ecole Royalo Mliltalre, Lab de Phys Plasmos, gELGILM Con. of European. Dg Xil Fusion Prog, BELGIUM Prof. R. Bouclaue, Laboratorlum voor Natuurkunde, BELGIUM Dr. P.H. Sakangka, UnIv Estadual, BRAZIL instituto De Pesqulsas Espaclasi-IMPE, ERAZIL Library. Atomic Enargy of Canada LImitod, CANAOA Dr. M.P. Bachynakl, MB Technologles, Inc., CANAOA Or. H.M. Skarsgard, Unly of Saskatchewan, CANAOA or. H. Bernard, University of Erltish Columbla, CAMAOA Prot. J. Telehanen, UnIv. of Montreal, CAHADA Prof. S.R. Sreenivesan, Unlverslty of delgary, CANAN Prot. Fudor W. Johnston, IMRS-Energle, CANADA Dr. C.R. James, UnIV. of AIberta, CMNDA Or. Pater Lukac, Komensketo Unlv, CZECMOSLOYNIA The Librarian, Culina Laboratory. ENGLND Mrs. S.A. HutehInson, JET LIbrary, EKGLAD C. Mouttet, Leb, de Physlque des Mll leux IOnlsés, FRAHCE J. Radet, CEH/CNDARACAE - Bat s06, FRANCE Dr. Tan Mual, Acadery Blbllographlc, HONG KOHG Preorint LIbrary, Cent Res inst Phys, HUAsar Dr. B. Dasgupta, Saha Inst, InDIA Dr. R.K. ChnajIani, VIkram UnIV. IROIA Dr. P. Kew, Institute for PInsa Ruscarch, INDIA Dr. PhIIIIp Rosentey, Isreel Inst Tech, ISRAEL Prof. 5. Cupeman, Tul Auly Univeralty, ISAREL LIbrarlan, Int'| Ctr Theo Phys, ITALY Prof. G. Rastagnt, UnIv 01 Padova, ITALY Mlss cielia de Palo, Assoc EURATOM-ENEA, ITALY BIbIloteca, del OHR EURATOH, ITNY Or. H. Yanato, Toshlbe Re d Dov, JAPA Prof. 1. Kewakeml, Atomlc Energy Res. Institute, JAPAN Prot. Kyojl Nishlkewe, Unty of HIroshlae, JAPAN DIrec. Dept. La. Toknuk Res, JAER!, JAPAM Prof. Sotosnl Iton, Kyushu Universlty, JAPAy Rasearch info Center. Negoya Univarslty, JAPA Prof. S, Tanoke, Kyoto Unlversity, JAPA LI brary, Kyoto un Iversity, JAPAN Prot. HobuyukI Inowe, UnIversity of Tokyo, JAPAN S. Mor I, JAERI, JAPAN HaH. Kim, Korea Advanced Energy Research Instltute, KOAEA Prot. D.I. Chol, Adv. Inst Scl a Tech, KOREA Prot. 日.S. LIIG, Unlversity of Walkato, NEW ZEALAND Institute of Plosima Physlcs, PECPLE'S REPUBLIC OF CHIHA Llorarian, Institute of Phys.. PEOPLE'S REPLALIC OF CHINA Llbrary, Tsing Hud UnIvarsity, PEOPLE'S REPUBLIC Of CHINA
I. LI, Southmest Inst. Phystics, PEOPLE'S REPUBLIC OF CHINA Prot. J.A.C. Cabrat, Inst Suderlar Tecn, PORTUGhl Dr. Octorlan Petrus, AL I CUzA UnIvarsity, ROMANIA Or. Jahan de Villiors, Plasina Physics, AEC, SO AFRICA Prof. M.A. Helleorg, UnIvarslty of Natal, SO AFRICA Fusion Div. LIbrary, JEN, SPAIN

Dr. Lennart Stanflo, University of IMAEA, SHEDEN Library, Royal Inst Tech. SWEDEN Prot. Hans WIthelmon, Chalmers UnIr Joch, SWEDEN Centre Phys des Plasmas, Ecole Polytach fod, SWITZERLAND BIbliotheek. Fom-Inst Yoor PIasma-Fysica, THE NETHERLANDS Dr. D.D. Ryutov, Siborlan Acod Scl, USSR Dr. G.A. EIIseev, Kurchator Institute, USSR Or. V.A. Glukhlkh, Inst Electro-Physlcal, USSR Or. V.T. Tolok, Inst, Phys, Tech, USSR Dr. L.M. Kovrlzhnykh, Institute Gen. Physles, USSR Prot. T.J.M. Boyd, Univ Col lege $\mathbf{N}$ wales, MALES Nueliear Ros. Establishment, Julleh Ltd., W. GERMANY Blbllothek, Inst. Fur Plasmaforschung, H. GERMANY Or. K. Schindier, Ruhr Unlversltat, H. GeRMari ASDEX Reading km, IPP/Maxtlanck-Institut fur Plaseaphysik, H. GeruAr Librarion, Hax-Planek Institut, $w$. GerHAwY prot, R.K. Janer, inst Phys, Yutoslavia 